УДК 619:616-078:636.8

(C) 2014

Коне М. С., кандидат ветеринарних наук, Корчан Л. М., кандидат ветеринарних наук Полтавська державна аграрна академія

Петренко А. А., лікар ветеринарної медицини, Опришко А. Л., лікар ветеринарної медицини ТОВ «Біоцентр», м. Полтава

\title{
ЕПІЗООТОЛОГІЧНІ ДАНІ ПАНЛЕЙКОПЕНІЇ КОТІВ ТА ПОРІВНЯЛЬНА ОЦНКА ЕФЕКТИВНОСТІ СХЕМ ЛІКУВАННЯ В ТОВ «БІОЦЕНТР», М. ПОЛТАВА
}

\section{Рецензент - кандидат ветеринарних наук I. І. Панікар}

Вивчено вікову й породну чутливість, сезонність виникнення та динаміку прояву панлейкопенії у котів в умовах ветеринарних клінік ТОВ «Біочентр» м. Полтава. Запропоновано різні схеми лікування панлейкопенії котів. Розроблено нову схему лікування панлейкопенії у котів. Встановлено, щьо панлейкопенія частіше реєструється серед котів віком від двох місяиів до одного року. Більш схильні до захворювання безпородні тварини. Хвороба має виражену сезонність, шчо проявлясться частішими випадками виникнення панлейкопеніӥ у весняно-літньо-осінній період. Запропонована нами схема забезпечує стовідсоткову терапевтичну ефективність.

Ключові слова: панлейкопенія, кішка, лікування, схема, ефективність.

Постановка проблеми. Панлейкопенія котів (чума котів, парвовірусна інфекція котячих, інфекційний ларинготрахеїт, котяча лихоманка, інфекційний ентерит) - висококонтагіозна інфекційна хвороба домашніх котів, що клінічно проявляється лейкопенією, лихоманкою, блювотою, сильною діареєю й крайнім зневодненням організму $[1,4]$.

Панлейкопенія на сьогодні лишається одним iз найпоширеніших інфекційних захворювань котів, що призводить до значних економічних $\mathrm{i}$ моральних втрат. Загальні економічні збитки від панлейкопенії складаються з затрат, пов'заних із загибеллю тварин та на проведення профілактичних, протиепізоотичних і лікувальних заходів $[2,5]$.

Аналіз останніх досліджень і публікацій, у яких започатковано розв'язання проблеми. Аналізуючи дані журналів реєстрації хворих тварин ветеринарних клінік ТОВ «Біоцентр» за 2010-2012 роки, можна зробити висновок, що місто Полтава $є$ неблагополучним стосовно пан- лейкопенії котів. Провідні лікарі ветеринарних клінік міста стверджують, що за останні роки почастішали випадки захворюваності кішок інфекційними хворобами, у тому числі й панлейкопенією. У зв'язку з цим виникає потреба в розробці нових ефективних схем лікування даної хвороби.

Діагностика захворювання складна й проводиться комплексно на підставі епізоотологічних даних, клінічних ознак та результатів лабораторних досліджень $[3,6,7]$.

Мета роботи - вивчити епізоотологічні дані панлейкопенії котів в умовах м. Полтава.

Завдання - провести порівняльну оцінку схем лікування та розробити найбільш ефективну схему терапії тварин.

Матеріали і методи досліджень. Дослідження проводилися в період 2010-2012 років на базі ветеринарних клінік ТОВ «Біоцентр» м. Полтава.

Для вивчення порівняльної ефективності різних схем лікування панлейкопенії у котів в умовах зазначених ветеринарних клінік ТОВ «Біоцентр» нами було відібрано три різні вікові групи тварин (по сім котів у кожній), хворих на гостру форму панлейкопенії. Тварин відбирали за принципом аналогів.

У процесі вивчення панлейкопенії кішок використовували епізоотологічний, клінічний методи дослідження, а також статистичний метод обробки отриманих результатів.

Результати досліджень. Для оцінки епізоотологічної ситуації щодо панлейкопенії в м. Полтава ми аналізували дані ветеринарної звітності щодо захворюваності котів у ветеринарних клініках ТОВ «Біоцентр». Результати аналізу породної сприйнятливості котів до панлейкопенії представлені в таблиці 1. 
ВЕТЕРИНАРНА МЕДИЦИНА

\begin{tabular}{|c|c|c|}
\hline \multicolumn{3}{|c|}{$\begin{array}{c}\text { 1. Породна сприйнятливість кішок } \\
\text { до панлейкопенії у ветеринарних клініках } \\
\text { ТОВ «Біоцентр» за 2010-2012 роки }\end{array}$} \\
\hline \multirow[t]{2}{*}{ Порода } & \multicolumn{2}{|c|}{$\begin{array}{c}\text { Захворіло } \\
\text { панлейкопенією }\end{array}$} \\
\hline & тварин & $\%$ \\
\hline Персидська & 8 & 15,1 \\
\hline Бірманська & 4 & 7,5 \\
\hline $\begin{array}{c}\text { Свропейська } \\
\text { короткошерстна }\end{array}$ & 6 & 11,3 \\
\hline Сіамська (малайська) & 2 & 3,8 \\
\hline Болінезійська & 3 & 5,7 \\
\hline $\begin{array}{c}\text { Британська } \\
\text { короткошерстна }\end{array}$ & 5 & 9,4 \\
\hline Безпородні & 25 & 47,2 \\
\hline Усього & 53 & 100,0 \\
\hline
\end{tabular}

\section{2. Вікова сприйнятливість котів до панлейкопенії за 2010-2012 роки}

\begin{tabular}{|c|c|c|}
\hline \multirow{2}{*}{ Вік хворих кішок } & \multicolumn{2}{|c|}{$\begin{array}{c}\text { Кількість } \\
\text { хворих тварин }\end{array}$} \\
\cline { 2 - 3 } & $\begin{array}{c}\text { абсолютне } \\
\text { число }\end{array}$ & $\%$ \\
\hline До 2 місяців & - & - \\
\hline Від 2 до 6 місяців & 21 & 39,6 \\
\hline Від 6 місяців до 1 року & 24 & 45,3 \\
\hline 1-2 роки & 5 & 9,4 \\
\hline 2-5 років & 3 & 5,7 \\
\hline Старше 5 років & - & - \\
\hline Усього & 53 & 100,0 \\
\hline
\end{tabular}

Примітка: - захворювання не реєстрували

Результати вивчення сезонності панлейкопенії

Iз отриманих даних встановлено, що частіше панлейкопенія котів у м. Полтава реєструється серед безпородних тварин $(47,2$ \% від загальної кількості хворих).

Дані про вікову динаміку панлейкопенії у котів в умовах ветеринарних клінік м. Полтава наведені в таблиці 2.

Як свідчать дані, представлені в таблиці 2, найчастіше панлейкопенія реєструється серед котів у віці від шести місяців до одного року $(45,3 \%)$, а також із двох до шести місяців $(39,6 \%)$.

Крім того необхідно звернути увагу на те, що кошенята до двох місяців не хворіють: це, на нашу думку, пов'язано з високим рівнем колострального імунітету, який формується за рахунок молозива матері.

в котів представлені в таблиці 3.

Аналізуючи отримані дані, ми встановили, що для панлейкопенії котів характерна сезонність перебігу. Частіше дане захворювання реєструється у весняно-літньо-осінній перід, але пік припадає на літо.

Із метою визначення ефективності різних схем терапії гострої форми панлейкопенії котів трьох сформованих груп лікували різними комплексами препаратів. Результати дослідження різних схем лікування котів у клініках ТОВ «Біоцентр» наведено в таблиці 4.

Як свідчать дані таблиці 4, найбільшу ефективність лікувальних заходів отримали за використання схеми, що включала: $5 \%$ «Енрофлокс», «Циклоферон», «Гамавіт», «Катозал» i «РБС-Кінг». Терапевтична ефективніть становить $100 \%$.

\section{3. Сезонність прояву панлейкопенії у кішок}

\begin{tabular}{|c|c|c|}
\hline \multirow{2}{*}{ Місяць } & \multicolumn{2}{|c|}{ Захворіло } \\
\cline { 2 - 3 } & тварин & $\%$ \\
\hline січень & - & - \\
\hline лютий & - & 5,7 \\
\hline березень & 3 & 5,7 \\
\hline квітень & 3 & 7,5 \\
\hline травень & 4 & 20,7 \\
\hline червень & 11 & 15,1 \\
\hline липень & 8 & 17,0 \\
\hline серпень & 9 & 13,2 \\
\hline вересень & 7 & 11,3 \\
\hline жовтень & 6 & 3,8 \\
\hline листопад & 2 & - \\
\hline грудень & - & 100,0 \\
\hline Усього & 53 & \\
\hline
\end{tabular}

Примітка: - захворювання не реєстрували 
4. Терапевтична ефективність різних схем лікування панлейкопенії котів $(n=7)$

\begin{tabular}{|c|c|c|c|c|c|}
\hline Група & Схема лікування & \multicolumn{2}{|c|}{ Одужало } & \multicolumn{2}{|c|}{ Загинуло } \\
\cline { 3 - 6 } тварин & тварин & $\%$ & тварин & $\%$ \\
\hline 1 & $\begin{array}{c}5 \% \text { «Енрофлокс»+ «Гамавіт»+ «Като- } \\
\text { зал»+ «Циклоферон»+ «РБС-Кінг» }\end{array}$ & 7 & 100 & - & - \\
\hline 2 & $\begin{array}{c}5 \% \text { «Енрофлокс»+ «Гамавіт»+ } \\
\text { «Катозал»+ «РБС-Кінг» }\end{array}$ & 5 & 71,4 & 2 & 28,6 \\
\hline 3 & $5 \%$ «Енрофлокс»+ «Гамавіт»+ \\
«Катозал» & 3 & 42,9 & 4 & 57,1 \\
\hline
\end{tabular}

\section{Висновки:}

1. На панлейкопенію хворіють коти різних порід, однак у більшості випадків дана патологія спостерігається серед безпорідних тварин (47,2 \%).

2. Ензоотія панлекопенії має виражену сезонніть (частіше - у весняно-літньо-осінній період).

3. Панлейкопенія реєструється в котів різного

\section{БІБЛІОГРАФІЯ}

1. Авдиенко B. A. Диагностика и терапия панлейкопении кошек / В. А. Авдиенко, К. В. Корнеева, А. Н. Авдиенко // Соврем. аспекты диагностики, профилактики и лечения инфекц. инваз. болезней животных. - М., 1998. - С. 67-72.

2. Авдиенко B.A. Панлейкопения кошек / В. А. Авдиенко // Московская государственная академия вет. медицины и биотехнологии им. К. И. Скрябина. - М., 1999. - 32 с.

3. Бірюкова T. A. Культуральні властивості вірусу панлейкопенії кішок / Т. А. Бірюкова, В. М. Колишкін, В. І. Усалов [та ін.] // Ветеринарія, 2000. - №10. - С. 22-25.

4. Вспышка панлейкопении кошек в г. Снежинске Челябинской области / Т. Н. Давыдова, Л. В. Галатова, Л. В. Кучеренко // Актуальные віку, але більш схильні до зараження тварини віком від двох місяців до одного року.

4. Розроблена нами схема лікування, що включає 5\%-й «Енрофлокс», «Циклоферон», «Гамавіт», «Катозал» і «РБС-Кінг» у дозах (відповідно до ваги тварини) має найвищу ефективність $(100 \%)$.

проблемы вет. медицины. - Троицк, 2002. C. $46-48$.

5. Родина В. П., Борисова И. Н. Опыт лечения панлейкопении кошек / В. П. Родина, И. Н. Борисова //Актуальные проблемы биологии и вет. медицины мелких домашних животных. - Урал, 2005. - C. 192.

6. Сулимов А. А. Вирусные болезни кошек / А. А. Сулимов. - Москва : Колос, 2004. -86 с.

7. Щербина Е. В. Применение препаратов гамавит, фоспренил, максидин в схемах лечения заболеваний мелких домашних животных различной этиологии / Е. В. Щербина // Матеріали 7-ї Міжнародної науково-практичної конференції «Проблеми ветеринарного обслуговування дрібних домашніх тварин». - Київ, 2002. - С. 83-85. 